\title{
Persoalan Ekonomi Indonesia Menjelang Liberalisasi Perdagangan Dunia
}

\author{
Oleh : Arief Ramelan Karseno
}

\begin{tabular}{|l|l|}
\hline & $\begin{array}{l}\text { Arief Ramelan Karseno, lahir di Yogyakarta 4 Juni } \\
\text { 1952 AlumniFakultas Ekonomi UGM(1979), sedangkan } \\
\text { MA diperoleh di University of the Philipines at Diliman, } \\
\text { Quezon City Philiphines (1984). Adapun Gelar Phd } \\
\text { diperoleh di University of Colorado at Boulder, Colorado } \\
\text { USA (1991). Saat ini sebagai dosen tetap pada } \\
\text { Almamaternya. Selain itu ia juga aktif melakukan } \\
\text { Penelitian-penelitian dan menulis Buku antara lain " } \\
\text { Mathematics for Ekonomic" }\end{array}$ \\
\end{tabular}

Pendahuluan

Perdagangan dan perdagangan antar bangsa selalu menjadi persoalan yang penting sepanjang masa. Sejak masa Adam Smith (1776), perdagangan selalu dipandang sebagai faktor utama pendorong kesejahteraan umat manusia. Pertukaran dan spesialisasi dipandang sebagai faktor utama pendorong pertumbuhan perekonomian. Perjalanan teori perdagangan internasional, selalu sejalan dengan 'thesis' tersebut di atas.

Keterbatasan jenis produk dan mobilitas sumber telah menjadikan dunia yang" penuh dengan "perbedaan produktivitas" berubah menjadi "relatif homogen". Buplikasi produk dan persaingan yang semakin ketat, menjadikan negara-negara menghadapi dilema di dalam kebijaksanaan perdagangannya. Disatu pihak, perdagangan dan intemasional terbtikti merupakan motor pertumbuhan ekonomi yang secara politik menguntungkan negara-bangsa, tetapi dilain pihak persaingan yang semakin ketat mengancam eksistensi negara-negara sebagai kesatuan politik.

Kekhawatiran akan kerugian atas perdagangan intemasional, mendorong negara untuk meningkatkan "barrier" perdagangannya, sedemikian sehingga pengusaha di dalam negeri dapat dilindungi secara aman dan bebas dari tekanan harga internasional. Kecenderungan ini disepakati sebagai sesuatu yang kurang sehat bagi perkembangan perekonomian dunia. Untuk itulah, GATT ditanda-tangani untuk pertama kalinya pada tanggal 30 Oktober 1947 oleh negara-negara yang sudah melihat peńtingnya perdagangan 
intemasional. Pada saat itu persetujuan GATT ditanda-tangani oleh hanya 23 negara. Sejak' itu peserta GATT menjadi semakin banyak, dan pada Uruguay Round 1986 ini negara peserta sudah mencapai 105 negara.

Meskipun demikian, efektivitas perjanjian GATT temyata sering dirasakan kurang. Hal ini disebabkan berhadapan dengan persoalan "konflik kepentingan" yang sifatnya lebih kecil. Munculnya blokblok perdagangan seperti MEE, NAFTA dan AFTA, adalah sebagian gambaran kurang kepercayaan masyarakat dunia temadapefektivitas GATT.Jugalambatnya proses perjanjian GATT putaran-Unuguay ini (1986-1993) menggambarkan besarnya konflik kepentingan yang harus diatasi.

\section{Arti Penting GATT dan APEC̀}

Hảsil persetujuan perdagangan multilateral GATT, putaran Unuguay ini menghasilkan sembilan kesimpulan utama. Kesimpulan itu adalah :

1. Kesepakatan untuk membuka "Market Access" ke negara peserta dan - penurunan "Tarif" secara sistematis.

2. Dibidang pertanian, hambatan perdagangan Non-Tarif (Non-Tarif Barrier) harus segera diubah menjadi hambatan Tarif.

3. Disetujuinya aturan main dalam liberalisasi perdagangan jasa (seperti Tourisme,'Komunikasi dan Perbankan). Business ini melibatkan kegiatan perdagangan senilai US\$ 4 Trilyun.

4. Perjanjian perdagangan Textile-Multi Fibre Agreement hans diakhiri dalam waktu 10 tahun.

5. Kesepakatan peraturan tentang intelectual Property Right. Seluruh perdagangan yang berkaitan dengan intelectual Property Right harus sudah diterapkan dalam waktu 10 tahun.

6. Liberalisasi atas Investasi Asing (TRIM) harus dilakukandalam periode $2-7$ tahun sejak perjanjian disepakati.

7. Kejelasan tentang implementasiundangundang atau peraturan Anti-Dumping yang diterapkan oleh negara peserta.

8. Kesepakatan untuk menyelesaikan secara efisien setiap persoalan sengketa perdagangan yang terjadi diantara negara peserta.

9. Persetujuan transformasi kelembagaan GATT menjadi WTO, yang dipandang akan lebih efektif di dalam penyelesaian persoalan perdagangan multilateral.

Kesepakatan GATT ini dipandang penting, khususnya oleh negara-negara maju. Dengan kesepakatan ini, hambatan perdagangan yang selama ini membatasi nuang gerak industri berskala besar, yang pada umumnya berada pada negara maju, dapat dihapuskan secara sangat significant. Stagnasi yang dialami beberapa negara industri dapat diatasi dengan kesepakatan ini.

Perkiraan yang dilakukan oleh Bank Dunia, menunjukkan bahwa dengan kesepakatan GATT, perdagangan dunia pada tahun 2003 dapat meningkat sebesar US\$ 213-274 miliar per tahun. Akibat dari perdagangan ini cukup besar, mengingat perdagangan selalu melibatkan multiplier kepada sektor-sektor yang lain. Pada tabel 1 berikut dapat dilihat seberapa penting perjanjian GATT terhadap peningkatan perdagangan bagi negara/region tertentù.

Secara umum dapat dikatakan bahwa negara yang mendapatkan manfaat dari trade liberalisation adalah negara-negara 
industri maju. Sedangkan bagi Indonesia persetujuan GATT ini sampai dengan tahun 2002 diperkirakan akan masih akan sangat merugikan. Perkiraan inipun didasarkan atas anggapan bahwa struktur perekonomian di Indonesia dalam keadaan normal, dan efisien.

Namun demikian, dari segi implementasi, GATT nampaknya akän sulit untuk diterapkán sebelum seluruh negara meratifikasi persetujuan ini serta sebelum pembentukan WTO menjadi suatu kenyataan. Sebelum ada suatu institusi yang mampu menjadi yuri didalam "permainan" ini maka GATT akan tenggelam dimakan waktu.
Pesimisme itu teláh mendorong Australia yang didukung USA untuk mempelopori dibentuknya kawasan perdagangan bebas yang lebih kécil, yaitu APEC (Asia Pacific Economic Cooperation), sebagai suatu usaha untuk mempercepat implèmentasi liberalisasi perdagangan pada suatukawasan yanglebih sempit, yaitu negara-negara disekitar "Lautan Teduh (Pacific Basin)". Dengan cara ini diharapkan idea GATT dapat lebih cepat terlaksana di kawasan Asia-Pasifik.

APEĆ pada dasamya adalah usahausaha yang bersifat lebih teknis untuksecara riil mengimplementasikan simpulansimpulan GATT. Secara umum APEC

Tabel 1

Dampak Liberalisasi Perdagangan Dunia Tahun 2002

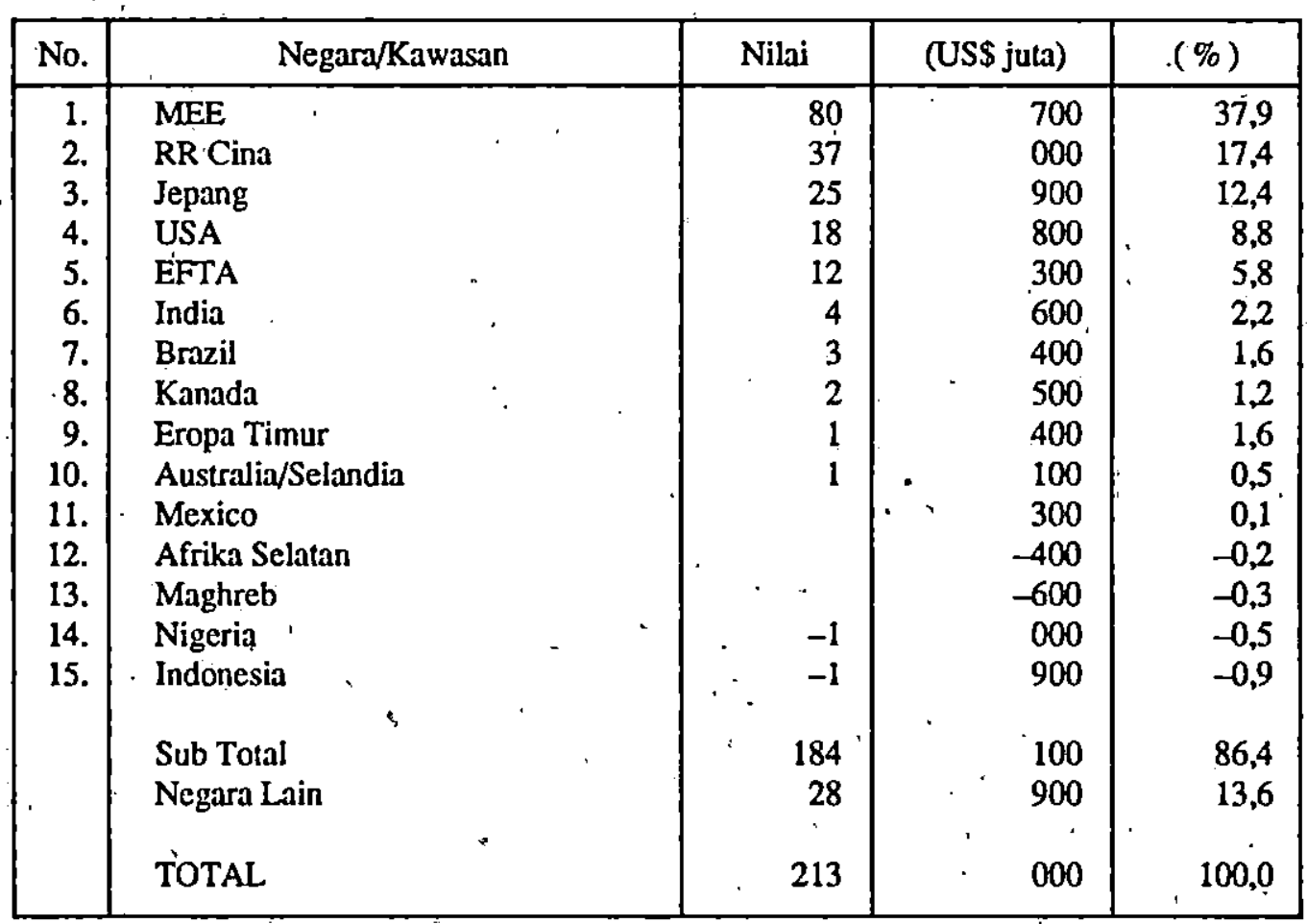

- Sumber : OECD dan World Bank (1992) 
dimaksudkan sebagai suatu kerjasamayang bersifat regional, yang terbuka kemungkinan kerjasamanya bagi non anggota. Atau dengan istilah lain "Open Regionálism".

Rekomendasi-rekomendasi yang dikeluarkan oleh "The Eminent Persons Group" (EPG) yang telah dibahas di Bogor pada tanggal 15 November 1994 itu antara lain mengusulkan agar negara-negara anggota APEC dapat meratifikasi kesepakatan Uruguay Round, secepatcepatnya, sehingga terbentuknya kawasan perdagangan bebas dapat dilakukan secepatnya.

EPG juga mengusulkan agar pemerintah negara anggota APEC segera melakukan penundingan untuk menyusun fasilitas (infrastruktur) investasi yang didasarkan atas prinsip-prinsip investasi tidak mengikat (Non-Binding Code Investment). Penyusunan infrastruktur itu antara lain dilakukan dengan cara mengurangi biaya-biaya transaksi dan ketidakpastian didalam negeri.

Selain itu EPG juga menyarankan dibentuknya lembaga yang menangani permasalahan perselisihan perdagangan dikawasan APEC (Dispute Mediation Services, DMS). Dari usulan-usulan EPG yang cukup menimbulkan perbedaan pendapat adalah permasalahan penetapan jadwal liberalisasi perdagangan dan investasi, yang diawali pada tahun 2000 dan-diakhiri pada tahun 2020. Hal penjadwalan ini akan mempersulit negaranegara yang masih merasa tertinggal didalam perdagangan internasionalnya, antaralain Malaysia dan China, tetapi dilain pihak akan menguntungkan bagi negaranegara besar seperti USA dan Jepang.
Persoalan bagi Indonesia

Persetujuan GATT dan APEC ini bagi Indonesia tentu ada untung dan ruginya. Keuntungan;dan kerugian ini akan sangat erat kaitannya dengan sistem pasar yang sudah ada di Indonesia selama ini.

Perlu dicatat, bahwa GATT dan APEC adalah perjanjian antar "pemerintah" suatu negara; sedang substansinya melibatkan lebih banyak pengusaha swasta di dalam negara tersebut. Dengan demikian kesepakatan GATT ini akan lebih banyak menekan kepentingan "pemerintah" daripada kepentingan "swasta". Dengan APEC ini pemerintah ditekan untuk dengan cepat memberikan "infrastruktur" baik fisik maupun dalam bentuk regulation yang akan meningkatkan kegiatan "swasta" di kawasan ini. Hal ini dikarenakan adanya anggapan bahwa hambatan perdagangan dan proteksi hanya bisa dilakukan oleh pemerintah. Ketidaksempumaan pasaryang terjadi pada suatu negara adalah tanggung jawab pemerintah semata. Apabila tidak terjadi "kesalahan" dalam peraturan pemerintah, distorsi atas efisiensi pasar tidak akan terjadi. Disini terlihat bahwa 'GATT dan. APEC akan merupakan ujian berat bagi pemerintah. Tetapi dilain pihak, akan merupakan "angin segar" bagi kegiatan sektor swasta (secara umum) yang terlibat didalam kegiatan ekonomi sekarang ini.

Dengan adanya pengurangan tarif dan liberalisasi akses pasar dalam negeri, akan menekan pemerintah untuk melepaskan proteksinya terhadap industriindustri manufakturi tertentu. Kita mengetahui bahwa selama ini proteksi pemerintah telah banyak menimbulkan masalah didalam - efisiensi dan konglomerasi. Dengan adanya GATT dan 
APEC ini, sebenamya efisiensi industri dalam negeri menjadi sangat penting artinya.

Namun demikian, dilain pihak perlindungan pemerintah atas industrikecil, rumah tangga dan petani juga menjadi sangat sulit untuk dilaksanakan. Kesepakatan Countervailing-Dutties méngijinkan suatu negara untukmembebani tarif yang cukup tinggi apabila temyata bahwa produk ekspor kita disubsidi (secara langsung maupun tidak langsung) oleh pemerintah.

Besamya proteksi pemerintah atas sektor industri kita dapat lihat pada tabel berikut ini.
Dari data tersebut, terlihat bahwa proteksi yang diberikan oleh pemerintah terhadap industri kita sampai dengan tahun 1992 masih sangat besar. Hal ini antara lain didasarkan atas argument "infant industry" yang saat ini sudah cukup tertinggi. Dengan dilaksanakannya perjanjian GATT, proteksi atas industri itu harus segera dikurangi, . sesuai dengan target yang disepakati.

Yang menarik untuk diamati ialah, dampak ekonomi apabila proteksi itu dihapuskandikemudian hari. Secara teoritis scharusnya penghapusan tarif itu akan merubah struktur pasar menjadi lebih baik. Memàsuki ke sektor industri yang bersangkutan segera tèrbuka, dan

\section{Tabel 2}

Struktur Proteksi Industri Manufaktur di Indonesia (\%)

\begin{tabular}{|l|r|r|r|r|r|r|r|r|r|}
\hline \multirow{2}{*}{ Sektor } & \multicolumn{3}{|c|}{ NRP } & \multicolumn{3}{c|}{ ERP } & \multicolumn{3}{|c|}{ RERP } \\
\cline { 2 - 9 } & 1987 & 1990 & 1992 & 1987 & 1990 & 1992 & 1987 & 1990 & 1992 \\
\hline Manufacturing & 17 & 13 & 12 & 68 & 59 & 52 & 50 & 43 & 37 \\
Food & & & & & & & & & \\
Textile & 14 & 13 & 12 & 122 & 126 & 120 & 99 & 103 & 99 \\
Wood & 32 & 12 & 12 & 102 & 35 & 34 & 81 & 21 & 11 \\
Páper & 2 & -5 & -5 & 25 & 33 & 33 & 12 & 20 & 20 \\
Chemicals & 22 & 13 & 12 & 31 & 20 & 20 & 17 & 8 & 8 \\
Non-Metal & 6 & 5 & 4 & 14 & 13 & 12 & 2 & 1 & 1 \\
Metal & 17 & 14 & 13 & 57 & 49 & 44 & 40 & 34 & 30 \\
Metal Product & 7 & 6 & 6 & 13 & 10 & 10 & 1 & -1 & -1 \\
Other. & 40 & 26 & 26 & 124 & 79 & 80 & 101 & 61 & 62 \\
& 40 & 26 & 26 & 124 & 79 & 80 & 101 & 61 & 62 \\
Import-competing & & & & & &. & & & \\
Export-competing & 17 & 15 & 15 & 39 & 35 & 32 & 24 & 21 & 19 \\
Anti-trade bias & -1 & -1 & -1 & -2 & -1 & -1 & -12 & -11 & -11 \\
& & &. & 41 & 36 & 33 & & & 1 \\
\hline
\end{tabular}

Sumber : World Bank, 1993 
pengusaha lain yang lebih efisien akan segera ikut berusaha dibidang itu. Dengan cara ini efisiensi pasar dalam negeri menjadi lebih baik.

Tetapikarenapelepasan proteksi atas sektorindustri ini didälam prakteknya hanya muncul sebagai akibat adanya tekanan pengusaha asing yang akan masuk ke sektor tersebut, maka calon pengusaha swasta "domestik" yang akan ikut masuk ke sektor ini tidak juga menjadi lebih mudah. Datangnya pesaing asing yang memiliki keunggulan akan merupakan pesaing baru bagi "calon" pengusaha yang selama ini belum diperhitungkan.

Dengan kata lain, pengusaha menengah dan kecil di Indonesia yang selama ini menunggu giliran untuk memperoleh fasilitas subsidi dan kemudahan masuk ke dalam sektor tertentu mungkin tidak jadi berminat lagi, karena hilangnya fasilitas subsidi pemerintah. Calon pengusaha yang belum pernah mendapatkan subsidi pemerintah ini, tidak bisa mengharap lagi adanya "protcksi/ subsidi" pemerintah, karena sesuai dengan GATT pemerintah dalam waktu dekatsudah tidak boleh lagi memberi "proteksi". Proteksi sudah bukan jamannya lagi, dan mereka harus berjuang sendiri tanpa bantuan pemerintah, melawan persaingan global.

Bagi pemerintah, periode Pasca GATT ini juga diwamai dengan banyaknya komitmen internasional yang secara langsung berkaitan dengan bisnis di Indonesia. Konflik kepentingan antara swasta domestik dan swasta asing harus diatasi oleh pemerintah. Negosiasi dan dispute setlement antara pengusaha-swasta asing dan domesting akan menjadi hal yang sangat biasa terjadi di dalam negeri. Dansayangnya hal ini akan selalu melibatkan pemerintah sebagai sumber dari semua jenis "regulasi".

Sehubungan dengan itu, pemerintah akan dituntut untuk memiliki sistem aturan perundangan yang jelas dan tidak menyesatkan. Keruwetan didalam sistem regulasi, akan menimbulkan masalah bagi pemerintah sendiri dan swasta domestik. Keruwetan regulaasi, akan menyebabkan pemerintah tersita tenaganya untuk melayani masalah perdagangan dengan pengusaha swasta asing, yang biasanya sangat "penuntut". Disamping itu, ketidak jelasan regulași juga akan menyulitkan pengusaha domestik sendiri untuk bisa bersaing dengan "lawan" internasionalnya.

Untuk mẹngatasi hal itu, pembenahan sistem perundang-undangan berikut aturan pelaksanaannya (infrastruktur politik dan ekonomi) merupakan syarat mutlak yang dalam waktu singkat harus dilaksanakan. Ketegasan pemerintah didalam pelaksanaan peraturan perdagangan merupakan "pre-requisite" bagi kcberhasilan bangsa ini masuk dalam sistem "internasional" yang penuh dengan "aturan-aturan hukum" yang saling terkait dan cenderung membingungkan.

Didalam praktek, karena pengusaha lokal lebih "penurut" sedang pengusaha asinglebih "agresif", maka pemerintah akan cenderung lebih banyakmelayani keinginan pengusaha asing daripada pengusaha domestik ini, apalagi melayani kepentingan desa tertinggal. Ini berarti bahwa didalam jangka menengah ini pengusaha swasta Indonesia harus menjadi lebih "agresif" dan lebih banyak menuntut haknya. Tanpa pola ini pengusaha dalam negeri akan mudah tersingkirkan oleh pesaing asing.

Namun demikian, karena sistem 
persaingạn internasional sekarang ini menjadi lebih banyak melibatkan pertentangan "legal", maka struktur biaya produksi akan lebih banyak dicurahkan kepada pengeluaran "overhead" dibidang "legal/hukum". Untuk kepentingan itu, LSM dibidanghukum perdaganganmenjadi sangat penting artinya.

\section{Kesimpulan dan Implikasi}

Persetujuan perdagangan multilateral GATT, putaran Uruguay, dan persetujuan APEC memiliki dampak yang sangat penting bagi perekonomian Indonesia dimasa datang. Subsidi kepada sektor pertanian yang diharapkan para pertani kita, kemungkinan besar dihapuskan secara total. Sebagai konsekuensinya, pemerintah tidak bisa lagi menuntut petani untuk mentargetkan pola tanam tertentu. Apabila hal ini masih juga dilaksanakan, maka beban "biaya opportunitas" yang dibebankan kepada petani menjadi semakin berat. Petani dan masyarakat umum diharapkan untuk menjadi pengusaha yang berkonotasi "swasta", yang memiliki sikap lebih agresif dan menuntut haknya yang dirasa belum dipenuhi oleh pihak lain.

Struktur industri yang "over-protected" harusdiakhiri, dan pengusaha swasta yanglebih efisien harus dapatmenggantikan pengusaha yang sekarang ini ada. Persoalannya, pengusaha "menengah dan kecil" yang akan muncul, akan menjumpai pesaing potensial yang berkualitas dạn berpengalaman intemasional. Oleh karena itu hanya pengusaha dengan ketangguhan "ganda" saja yang akan mampu bertahan hidup dimasa datang. Dan ini biasanya pengusahà yang memiliki keunggulan kompetitif dari yang lain.
Kecuali itu, berkembàngnya persaingan dagang kearah pertentangan "hukum", menuntut adanya perbaikan sistem regulasi yangada. Hal ini merupakan infrastruktur ekonomi yang segera harus disediakan oleh pihak pemerintah (atau pimpinan ekonomi negara). "Ketidak jelasan" dan "kurang transparan"-nyaproses penetapan regulasi dan perundangundangan khususnya dibidang perdagangan, akan menyusahkan pemerintah sendiri serta pengusaha swasta "domestik" dalam menghadapi persaingan intemasional.

Bagi pemerintah, keruwetan regulasi didalam negeri, akan memperlambat "bargaining position"-nya didalam "dispute settlement" dengan pihak asing. Perbedaan pengertian "hukum" antara pemerintah dan masyarakat akan selalu dimańfaatkan oleh pihak asing untuk kepentingannya.

Konsekuensi dari hal ini semua, struktur organisasi departemen dan negara harus disesuaikan dengan tuntutan ekonomi dunia ini. Pengambilan keputusan ekonomi nasional yang selama ini tidak terlalu diabaikan sebagai bagian dari demokrasi kita, seharusnya secara eksplisit ditegaskan kembali oleh pemerintah. Kegiatan Partai Politik, Golkar dan anggota DPR yang selama ini tidak terlalu cepat tanggap terhadap dinamika ekonomi dunia harus dibenahi. Hal ini merupakan titik kritis bagi keikut sertaan masyarakat umum yang tidak tergolong kedalam kelompok "pengusaha-swasta" untuk mengambil keputusan bisnis nasional yang penting, yang pada gilirannya àkan membebaninya.

Kelompok masyarakat "pengusahaswasta". (besar) pada dasamya telah terlibat didalam proses pengambilan keputusan baik 
nasional maupun intemasional. Dan keputusan mereka ini sedikit banyak aḱan menyulitkan sebagian besar masyarakat yang lainnya. Sebagai contoh, usulan kelompok pengusaha Indonesia yang tergabung dalam "Pacific Business Forum" yang menyarankan pelaksanaan "freetrade" pada tahun 2020, lebih cepat dari usulan EPG (Eminent Person Group), akan memiliki dampak tekanan liberalisasi yang lebih cepat, dan kesulitan infrastruktur nasional yang lebih dini. Padahal tidak banyak diantara kita yang mengenal siapasiapa saja yang ikut dudukmewakili "swasta Indonesia" di forum itu.

Dengan demikian, penyempumaan "Sistem Komunikasi antara MasyarakatPemerintah (dalam hal ini Pimpinan masyarakat luas dan pengusaha kecil didalam arus ekonomi global yang sangat dinamis ini.. Dalam hal ini Departemen Penerangan memegang peran sangat strategis.

\section{Réferensi}

Schoott, Jeffrey: "Competing The Uruguay Round", Institute for International Economics, Washington, 1990.

Dam, Keneth W: "The GATT, Law and International Economics Organization" The University of Chicago Press, Chicago, 1970.

Hoekman, B and Mavroidis, P: "Competition. Competition Policy and The GATT, Policy Research Working Paper 1228, The Work Bank, 1993.

Second Report of the Eminent Person Group: "Achieving The GATT Vosion:Free and OpenTrade in The AsiaPacific",'August 1994. 